\title{
JEFFERSON HIGHWAY ASSOCIATION
}

(An address given by Hugh H. Shepard, Mason City, Iozea, Life Director and Past International President of the Jefferson Highway Association, before the Sixteenth Annual Convention of the United States Good Roads Association at Des Moines on May 30, 1928.)

I have been asked to appear before this convention to give a little sketch of the history of the Jefferson Highway Association, and to show how the organization of the Jefferson Highway has contributed to the building of good roads and to the promotion of international good will.

It has been my fortune, and for the most part I could call it good fortune, to have become identified with the good roads movement in an active way in the fall of 1914, and to have continued to take a more or less active part since that time, as an amateur, in the promotion of good roads everywhere, particularly in the Middle West and along the route traversed by the Jefferson Highway from Winnipeg to New Orleans.

During this time a vast amount of correspondence, a considerable number of newspaper clippings and not a few maps have been collected that grow more interesting with the passing of the years.

The invention of the automobile made it necessary that good roads should be built so that the owners of the automobiles could travel from place to place with comfort, speed and safety, and the development of the automobile has been so rapid and so recent that it seems but yesterday since the old fashioned horse and buggy afforded the favored means of local transportation throughout the entire country, and when the roads were too muddy for travel by horse and buggy, the only means of travel was on horseback or on foot. When the roads became too bad the people stayed at home and waited for the roads to dry.

During the last twenty years there has been a complete revolution in the mode of transportation, and the automobile has developed from a curiosity until it occupies a permanent and very important position in our everyday life, and is no longer regarded as a luxury but has developed to a point where it is estimated that 85 to 90 per cent of the travel of the country is conducted in automobiles, and the transportation of commodities 
by means of motor trucks has increased by leaps and bounds, so today the horse-drawn vehicle is a matter of curiosity in many portions of the country. Livery stables have become a thing of the past and it is no longer possible to rent a horse-drawn vehicle to take a nccessary trip either in summer or winter.

This changing condition of affairs has made it necessary for good roads to be built so that the automobile can be used as an all year means of transportation, and it is the purpose of this address to show briefly how the change has come about in so short a space of time, and to show what other important benefits have been gained while these changes and improvements in road conditions were being accomplished.

The changes that have occurred along the route of the Jefferson Highway from Winnipeg to New Orleans are typical of the improvements and changes that have been made to a greater or less degree over the entire country, so we will return to the original subject of this address and give a brief sketch of some of the interesting events that have happened along the route of the Jefferson Highway since the good roads idea first began to develop.

On March 14, 1911, the Des Moines-Kansas City-St. Joseph Interstate Trail was organized at Lamoni, Iowa, and the road from Des Moines to Kansas City by way of St. Joseph was located and marked soon after by the association, assisted by automobile clubs, commercial organizations, farmers and other citizens in the cities, towns and country traversed by the trail.

The original organization meeting was called by W. A. Hopkins, banker and public spirited citizen of Lamoni, Iowa. The preamble to the constitution and by-laws adopted by the Interstate Trail Association on March 11, 1913, recites that "the representatives of the Des Moines, Kansas City and St. Joseph Interstate Trail Association, realizing that a permanent, wellkept highway connecting Des Moines, Kansas City and St. Joseph, and constituting nearly a direct route between Fort Des Moines and Fort Leavenworth, making a practical military road for the transportation of troops, would be a valuable aid in developing the resources of the counties traversed, a better means of social and business communication, and a lasting benefit to the communities through which it passes, have located and do undertake to improve and maintain such a road." 
On January 5, 1915, a meeting was held at Mason City, at which the original Interstate 'Trail was extended north from Des Moines through Nevada, Iowa Falls, Mason City, and Northwood, Iowa and Albert Lea, Owatonna, Faribault, and Northfield to St. Paul, Minnesota, and the name of the association was changed to the St. Paul-Des Moines-St. Joseph-Kansas City Interstate Trail, and Hugh H. Shepard of Mason City, who called and organized the meeting, was selected as general manager of the northern division of the Interstate Trail from Des Moines to St. Paul, and organized and marked the highway during the summer of 1915 from Des Moines to St. Paul, a distance of 271 miles.

Local trustees were selected in each of the communities through which the Interstate Trail passed between St. Paul and Kansas City, a distance of $\check{503}$ miles, and this well marked and well organized highway attracted a considerable amount of travel during the summer of 1915 . The road was located on a part of the Minnesota State Highway System in Minnesota and formed a part of the preferred road system for the entire distance across Iowa and for the greater part was located on the State Road System in Missouri, and connected the northwestern territory centering about the Twin Cities with the southwestern territory tributary to Kansas City, being a short and direct route that with the exception of one county in Iowa connected all of the county seat towns and cities for its entire distance.

The Interstate Trail was thoroughly organized with general officers and local trustees, all of whom performed their duties without compensation, and the expenses of the association were paid by voluntary contributions which were sufficient to get the desired results. The officers and trustees were without exception men of integrity and of high standing in their local communities, who recognized the development of good roads as a proper community service and gladly devoted their time without pay in working for the good roads movement, and co-operated on the ground with state and county authorities in the work of actually completing the building of a dependable road.

The idea foremost in the minds of the organizers of the Interstate Trail was to get the most practical and direct route between terminals and never to let personal influence enter into the selection of such a route. 
The Jefferson Highway Association was organized at New Orleans on November 15 and 16, 1915. The meeting was called by Walter Parker, general manager of the New Orleans Association of Commerce, at the instance and suggestion of the Honorable E. T. Meredith of Des Moines, who was afterwards United States secretary of agriculture in the administration of President Woodrow Wilson. Mr. Parker had no previous experience in the good roads work so he extended a general invitation to communities in the Mississippi Valley from points 200 miles and more apart cast and west for the purpose of organizing, marking and building a great north and south highway to extend from Winnipeg, Manitoba, in the north, to New Orleans, Louisiana, in the south.

The organization meeting was presided over by former United States Senator Lafayette Young of Des Moines, who conducted his duties with such marked skill that he brought order out of chaos and after two stormy days consumed by many speeches and much parliamentary discussion, the organization of the Jefferson Highway was completed and its terminal points were fixed.

The Interstate Trail organization was represented by delegates representing the entire 500 miles between St. Paul and Kansas City, including J. H. Beek, secretary of the St. Paul Association of Commerce, Herman Roe of Northfield, secretary of the Minnesota Editorial Association, Senator Thomas E. Cashman of Owatonna, and George $\dot{W}$. Cooley, highway commissioner of the state of Minnesota, was also in attendance at the meeting and was a close observer of the proceedings.

The states of Iowa and Missouri were well represented, and the Interstate Trail organization furnished the backbone for the new Jefferson Highway Association with its more than 500 miles of well organized and well marked highway. The plan of organization and the system of marking followed by the Interstate Trail was largely followed in the Jefferson Highway organization, and five of the early organizers of the Interstate Trail Association afterwards became international presidents of the Jefferson Highway Association, as follows: W. A. Hopkins of Lamoni, Iowa; Ezra H. Frisby of Bethany, Missouri; Thomas E. Cashman of Owatonna, Minnesota; Hugh H. Shepard of 
Mason City, Iowa; and the present president, George E. McIninch of St. Joseph, Missouri.

Representatives from Omaha, Sioux City, Sioux Falls and other points were in attendance at the organization meeting of the Jefferson Highway Association, but the offer made by the Interstate Trail Association of furnishing more than 500 miles of organized and marked highway connecting by a direct line the important terminals of St. Paul and Kansas City, was too great, and the other competing communities were unsuccessful in their efforts to secure the Jefferson Highway, but the enthusiasm developed at this great good roads meeting was such that a number of other highway organizations were adopted and the building of good roads in the Middle West received a great impetus as the result of the organization of the Jefferson Highway, not only along the Jefferson Highway itself, but along the competing routes that were started in friendly rivalry by the unsuccessful contestants who failed to get the location of the Jefferson Highway for their communities.

The cardinal points of the Jefferson Highway Association were located at New Orleans, Baton Rouge, Alexandria, Shreveport, Denison, Muskogee, Joplin, Kansas City, St. Joseph, Des Moines, St. Paul, Minneapolis, and Winnipeg.

After the organization of the Jefferson Highway Association had been completed, the delegates went home to undertake the work of building the highway on the ground and of getting the highway properly marked and advertised. The situation was ably expressed in an editorial that appeared in the Sioux City Journal on November 20, 1915. Sioux City lost out in the fight for the Jefferson Highway after being a strong contender for a location on the great transcontinental automobile highway that was to connect Winnipeg with New Orleans. The editorial states:

Even if the conference should decide in favor of one route as the official one, there is no reason why the promoters of other routes cannot go ahead and build competing highways. There is no such thing as monopoly in transcontinental highway building. The more good roads there are the merrier for all concerned. The more cities connected by transcontinental lines east and west or north and south the better it will be, not only for transcontinental travelers but for the cities and farming cornmunicios along each route. 'The good road is contagious. When one 
permanent or well-kept highway is introduced in a neighlborhood, the normal tendency is to bring the others up to its standard. A trunk line good road invites the building of good "spurs" connecting with it. In time the little leaven is bound to leaven the whole lump.

The important thing in the roads problem is to keep the public interested in a steady effort to improve existing road standards. If a fight over a proposed route contributes to this end it is helpful to the general cause of good roads whether it results in the building of one road or two, or none. The main thing is to keep the ferment working.

At the meeting of the Second Convention of the Northwestern Road Congress held in Cedar Rapids, Iowa, on October 5, 1915, a very interesting talk was given by $\mathrm{J}$. D. Clarkson, president of the 365-Day Road Club of Carthage, Missouri, entitled "Putting the People in the Problem." In his talk Mr. Clarkson told of the community work that had been done in his locality in getting dependable farm-to-market roads built in the vicinity of Carthage, Missouri.

Mr. Clarkson's talk made a very favorable impression on the convention and when the Jefferson Highway Association held its first directors' meeting at Kansas City, Missouri, on February 3,1916 , E. T. Meredith as first president of the Jefferson Highway Association, selected J. D. Clarkson as general manager of the Jefferson Highway Association. Mr. Clarkson had previously visited several of the towns along the Interstate Trail between Des Moines and St. Paul and found the people of each community willing and anxious to be shown the way to get good roads built on the ground.

As one of his first duties as general manager, Mr. Clarkson drove over three contesting routes nortlıwest of the Twin Cities in the state of Minnesota and by a system of scoring selected the route of the Jefferson Highway northwest of the Twin Cities, to run through Little Falls, Wadena, Park Rapids, Itasca State Park, including the head waters of the Mississippi River, Bemidji, Red Lake Falls, Thief River Falls, Hallock, and Emerson, located on the Red River just south of Winnipeg.

Communities on the unsuccessful routes in Minnesota were stimulated to an appreciation of the value of good roads, with the result that the Ten Thousand Lakes of Minnesota Association was organized, also the Minnesota Scenic Highway Association, and with the succession of Charles M. Babcock as high- 
way commissioner of Minnesota an amendment to the constitution of Minnesota was adopted permitting the bonding of the state for the issuance of road bonds, and the Jefferson Highway in the State of Minnesota is now fully paved, mostly with concrete paving, from Little Falls, Minnesota, throngh the Twin Cities south to the Freeborn County line, and the remaining county in Minnesota will be paved within the coming year.

Other paving projects in Minnesota were made on other highways connecting, with the Jefferson Highway, the 180 mile stretch from Duluth, Minnesota, to St. Paul, being a notable instance, and a good roads program has been adopted that will ultimately pave the main traveled highways in Minnesota and gravel the tributary highways of lesser importance.

In the state of Iowa Federal Aid Project No. 1 was established between Mason City and Clear Lake, resulting in the completion of a paved highway connecting Mason City on the Jefferson Highway with the delightful summer resort, Clear Lake, ten miles distant. This paving was extended east and west and south from Mason City. Waterloo, Sioux City, Davenport and Des Moines followed with paving projects and numerous counties in Iowa voted bonds for paving their primary roads, four counties on the Jefferson Highway in Iowa voting bond issues last fall that will complete a paved highway from Des Moines to the Missouri line, and from Mason City to the Minnesota line.

A special session of the Iowa legislature held in March, 1928, voted to submit a constitutional amendment to the voters of the state at the general election to be held in November that will provide a one hundred million dollar bond issue that will complete the paving on the principal primary roads of the state and will gravel the less important highways tributary thereto. If this bond issue carries it is expected that the Jefferson Highway will be completely paved across the state of Iowa by the end of the year 1929, and paving is now in progress in the counties of Worth, Franklin, Warren, Clarke, and Decatur.

In the state of Missouri bond issues were voted and the Jefferson Highway is now entirely paved from a point but two miles south of the Iowa line through the cities of Bethany, Stanberry, St. Joseph, and Kansas City, extending south to Joplin. 
A large portion of the paving has been completed in Kansas between Kansas City and Joplin running through the towns of Fort Scott and Pittsburg, Kansas. The greater portion of the paving has been completed on the Jefferson Highway in the states of Oklahoma and Texas, and a large amount of paving has been done in the state of Louisiana and the balance of the entire Jefferson Highway through Louisiana has been hard surfaced and graveled.

The short line between Joplin, Missouri, and Shreveport, Louisiana, was not adopted at the original Jefferson Highway meeting in New Orleans because there were at that time no roads across western Arkansas that could be traveled. The state of Arkansas has voted bond issues, has established a gasoline tax of four cents a gallon and has reccived federal aid for its principal roads and is rapidly completing the paving of its roads across the state.

'The present president and treasurer of the Jefferson Highway Association made a trip through Arkansas last month and have given a favorable report to the adoption of the short cut across Arkansas connecting Joplin, Missouri, with Shreveport, Louisiana, that will save a distance of nearly 270 miles for tourists who are bound for New Orleans, while the tourists bound for southwestern points will continue to use the original Jefferson Highway as established through Joplin, Muskogee and Denison, Texas.

In Manitoba the Jefferson Highway has been graded and graveled from the International boundary line to Winnipeg, so it may well be said that the Jefferson Highway for its entire distance from Winnipeg to New Orleans will be fully hard surfaced by the end of the year 1929, and the dream of the sturdy band of good roads enthusiasts who organized the Jefferson Highway in 1915 will have become a reality, and the travelers from North and South will find a completed highway on the ground suitable for travel 365 days in the year and well marked so that there will be no danger of losing one's way.

In May, 1925, a meeting was held in Kansas City, Missouri, attended by E. W. James of the United States Bureau of Grood Roads and the highway commissioners from eleven states in the Mississippi Valley from Louisiana to Minnesota and North Da- 
kota, at which time the principal highways of the Mississippi Valley were selected and recognized and were later designated as a part of the United States Highway System and are now designated by United States highway numbers.

The work of the Jefferson Highway pioneers was so well done and the highway so carefully selected that the Jefferson Highway for practically its entire distance was placed on numbered United States Highways forming a part of the main trunk line system of highways of the United States.

The numbered United States Highways for the most part follow meridian lines and the Jefferson Highway was organized to serve population centers and to attract the tourists to points of greatest interest along the way between New Orleans and Winnipeg that are not in a meridian line, so the Jefferson Highway does not have a continuous United States number, but is located on and forms a part of several United States highways.

At the annual meeting of the Jefferson Highway Association held last month in St. Paul, Minnesota, it was unanimously resolved that the Jefferson Highway has been of such historical importance in pioneering the good roads movement in the Mississippi Valley in linking up communities, county seats, state capitals and industrial and population centers, that its identity should be preserved, that it should retain its distinctive marking and that it should continue to be advertised as the main north and south highway of the Middle West, attracting the tourists and travelers from Pine to Palm in fall and winter, and from Palm to Pine in spring and summer, and it is hoped that the importance of pioneer transcontinental highways like the Lincoln Highway and the Jefferson Highway shall be nationally appreciated, and that the location and memory of these highways shall be perpetuated to posterity.

While the work of building the Jefferson Highway on the ground was progressing to the material advancement of the people along the way, it became evident that the opening up of the avenues of travel brought a closer relationship between town and country, between adjoining communities, between neighboring states, and also between more remote sections along the highway, both in the United States and in Canada. 
The gencral manager, J. D. Clarkson, who had active charge of the organization of the Jefferson Highway during its earlier years, was quick to sce the advantage of promoting an interchange of friendly relations between the communities along the highway and the first relay sociability run over the Jefferson Highway left St. Joseph, Missouri, on July 20, 1916, and continued north to St. Paul and thence on to Winnipeg. That such a run could be held eight months after the organization of the great north and south international highway is a fact of historical importance.

Enthusiastic receptions marked the progress of the run all along the way from the very start. It seemed, and was, a national event. Five thousand persons and 500 automobiles were present in Bethany, Missouri, where the first night's stop was made. The members of the party were entertained by prominent citizens and civic organizations all along the way, and the members of the sociability run delivered addresses to the citizens of the communities.

At the boundary between the United States and Canada, 66 miles from Winnipeg, the Jefferson Highway party was met by Premier T. C. Norris of the province of Manitoba, and party. The American party had been carrying a large American flag 5 by 8 feet in size, flying from a mast in the rear of the official car. Premier Norris presented the highway party with the Manitoba flag, and a representative of Mayor R. D. Waugh of Winnipeg presented the British flag with appropriate remarks as to the cordial relations existing between the two countries.

In accepting these flags; Mr. Clarkson, general manager, and Mr. Walter Parker of the New Orleans Association of Commerce, expressed their appreciation of the honor done the Jefferson Highway Association and the American representatives in the tender of these flags, and expressed the hope that as the flags thus waved in unison from a single staff, that this act would be typical of the action of the two peoples in joining forces for the completion of this great international highway, and it was predicted that the friendly relations of the last century will be duplicated in the coming century.

It was further stated that as the official car proceeded on its way south, its journey would not be terminated until the two 
flags floated in harmony over the battlefield at New Orleans where Britain and America last met in armed conflict over a hundred years ago, and it was hoped that perpetual peace would endure between the two peoples.

The United States entered the World War April 6, 1917, after the Canadians and the European allies had been carrying on for some time.

As an evidence of international good will and as an expression of gratitude to the people of the United States for the entry of the United States in the World War, a party of Winnipeg and Manitoba officials left Winnipeg, Manitoba, Monday morning, May 14, 1917, one minute behind schedule time, destined for New Orleans. The party was headed by Premicr T. C. Norris of Manitoba, Mayor Frederick H. Davidson, Commissioner W. F. Tallman, Commissioner J. A. MacDonald, all of Winnipeg, and twenty-one others, and the party drove through to Thief River Falls, Minnesota, for the first night control, the run being made over the famous old Pembina Trail that formed a part of the Jefferson Highway. The second night control was made at Itasca State Park at the headwaters of the Mississippi River.

The third night control was made at St. Cloud, Minnesota; the fourth night control at Albert Lea, Minnesota, and at the Iowa State line the party was met by the officials of the Iowa State Highway Commission; Hugh H. Shepard of Mason City, director for northern Iowa, and J. F. Harvey of Leon, director for southern Iowa, and the highway commissioners and Jefferson Highway directors accompanied the party through Iowa.

The fifth night control was held at Des Moines, and the party was entertained by the Des Moines Club at a splendid banquet. Talks were made all along the way by the members of the Canadian party and hundreds of small British and Canadian flags were presented to the enthusiastic crowds who were everywhere in evidence all along the way.

The trip continued southward, enthusiasm increasing as the party approached New Orleans, and the Jefferson Highway party turned the corner of Canal and St. Charles streets in New Orleans at the moment a neighboring clock chimed the hour of six on the afternoon of May 31, 1917, having completed the first half of an international good will trip of more than 2,300 
miles. The trip started as a sociability run. But three cars made the entire trip from Winnipeg to New Orleans, but scores of cars joined the tour for distances of 10 to 250 miles, and Premier Norris and Mayor Davidson were greeted with the warmest enthusiasm at every stop. They talked good roads, the Jefferson Highway, international sociability, at every stop, but everywhere the people wanted to hear Premier Norris talk of the war, which he did, and he told how Canadians had responded to the call, and he brought the message to Americans to realize that not only the government but every individual had a duty and an opportunity.

In Winnipeg the party was told they would never get to St. Paul. In Kansas City they were told that the Interstate Trail had brought them that far but that it would be impossible to continue southward. In Oklahoma the Texas roads were disparaged, and in 'Texas Mayor Davidson was advised that he would be sure to come to grief in some Louisiana swamp, but the party succeded in getting through and arrived in New Orleans on time.

Escorted by a hundred gaily bedecked automobiles the Jefferson Highway Association's tour ended in Winnipeg on June 29, 1917 , in the afternoon, completing a 4,500 mile trip to New Orleans and return on schedule time.

The significance and importance of the Jefferson Highway in cementing good will between Canada and the United States was most ably expressed in the letter written by Premier T. C. Norris after the completion of his trip to New Orleans and return, addressed to J. D. Clarkson, general manager of the Jefferson Highway Association. In his letter Mr. Norris states:

I desire to express to you my appreciation of the opportunity to make such an unusual trip as we have just completed. To say that we enjoyed the trip immensely is putting it very mildly. It was most interesting, instructive and entertaining all the way. The cordiality of welcome and the delightful hospitality of the people along the highway is very much appreciated by Canadians. The real fellowship and brotherhood existing between the two great Anglo-Saxon nations is evidenced by the very keen interest the people have taken in the visit of the Canadians.

We found the best people of each community interested in and working for the Jefferson Highway, and proud to know that the road touched 
their part of the country. The route of the highway seems to have been selected with the greatest care. There are no natural difficulties worth speaking of. It traverses a most wonderful country, amazingly fertile and abounding in natural wealth from the North to the South. There is practically no useless territory. The natural scenery is beautiful, and in many cases it is a continuous panorama of strange sights, of a most interesting character to Canadians.

The highway is not merely a road, but a "big idea" that means the linking up of communities, states, and the two great countries. The farr-reaching effect cannot be foretold by the most optimistic. It will have a commercial and social value and only time can demonstrate the extent of it.

The trip demonstrated that the Jefferson Highway is thoroughly practicable and there is no reason why it should not be completed in a very short time. I am pleased that you interviewed the Canadians and asked us to join you in the great undertaking, thus completing the road to the City of Winnipeg and thereby making it an international highway.

At exactly 9:30 A. M. on Tuesday, July 1, 1919, there started from the granite shaft at St. Charles and Common streets in New Orleans, this shaft being the marker of the southern terminus of the Jefferson Highway, a very unique and historymaking cavalcade. It was the party comprising the Jefferson Highway sociability run from New Orleans to Winnipeg, Canada, a distance of 2,400 miles, and crossing seven states before reaching the province of Manitoba.

The party was headed by Governor R. G. Pleasant of Louisiana and Highway Commissioner Buie in the latter's car. Immediately following was the big Packard of Martin Behrman of New Orleans. The party was piloted by J. D. Clarkson; manager of the Jefferson Highway. -The procession encountered rain on leaving New Orleans and the only car to reach Baton Rouge, the first night control, was Mayor Behrman. Mayor Behrman's car took the wrong road the following day and became stranded and it took three yoke of oxen and four mules and nearly the entire day to get the car out of the mud, the Louisiana roads being heavy and almost impassable on account of a six months' season of heavy rain.

The party was fully assembled and left Alexandria, Louisiana, on the morning of July 4, one day behind schedule. Honorable John McW. Ford, mayor of Shreveport, joined the party at Shreveport, accompanied by Mrs. Ford. 
Talks were made in the various towns along the highway. Honorable Thomas $H$. Johnson, attorney general of Manitoba and president of the Jefferson Highway Association, met the party at St. Joseph, Missouri.

Governor Allen of Kansas joined the party at Pittsburg, Kansas, Governor Harding at Des Moines, Iowa, Governor Bernquist of Minnesota at St. Paul, and Governor Gardiner of Missouri sent George E. McIninch of St. Joscph as his personal representative who accompanied the party. to Winnipeg.

The highway was well marked with Jefferson Highway markings from St. Joseph to Winnipeg. On the afternoon of July 21 the caravan rolled into Winnipeg and were ofincially received by the city of Winnipeg, the province of Manitoba, and the entire party were taken by special train 150 miles west to attend the Provincial Fair at the city of Brandon. A dinner was given the party by Sir James Aiken, lieutenant governor of the province of Manitoba, and the entire trip was characterized by expressions of international good will.

The Louisiana party were much interested in inspecting the headwaters of the Mississippi River at Itasca State Park, Minnesota, and an interesting photograph was taken of Governor Pleasant, Mayors Behrman and Ford and Highway Commissioner Duncan Buie spanning the Mississippi at its source.

The educational value of this trip was such that Highway Commissioner Duncan Buie, with the assistance and co-operation of Governor Pleasant and mayors Behrman and Ford and others, immediately adopted a good roads program in the state of Louisiana, draining swamps and clearing forests and building and grading the Jefferson Highway across the entire state of Louisiana, and the state of Lonisiana was the first state along the Jefferson Highway to complete the hard surfacing of the Jefferson Highway for the entire distance across its borders.

In August, 1925, a sociability run was again conducted north to Winnipeg, headed by Hugh $\mathrm{H}$. Shepard of Mason City, Iowa: president of the Jefferson Highway Association. The Jefferson Highway party was met at the international boundary by prominent citizens and officials from Winnipeg and Manitoba, were presented with the keys, and freedom of the city of Winnipeg by Mayor Ralph H. Webb, mayor of Winnipeg, and were enter- 
tained at a dinner at the Marlborough Hotel, in which Winnipeg pledged renewed loyalty to the Jefferson Highway Association.

On Saturday, January 23, 1926, a party of 115 Canadians left Winnipeg in the dead of winter in a forty-mile-an-hour blizzard, for an automobile tour over the Jefferson Highway to New Orleans and return. The trip was headed by Colonel Ralph H. Webb, mayor of Winnipeg, vice president of the Jefferson Highway Association, and was sponsored by the Winnipeg Tribune. Representatives of the city of Winnipeg, the province of Manitoba and of the Canadian government accompanied the party and numerous civic and commercial organizations sent representatives.

The party was successful in getting through Minnesota and Iowa without encountering snowstorms and conducted a scheduled trip along the entire trip from Winnipeg to New Orleans, arriving in New Orleans on Thursday evening, February 4. The adventurous party made history in conducting a trip of this kind in the dead of winter, and a number of the cars in the party were enabled to make the entire trip without the use of chains. Communities along the way turned out enmasse to welcome the Canadians and the friends from northern portions of the Jefferson Highway who accompanied them on this trip.

At a dinner given the Pine to Palm tourists, Colonel Webb expressed the sentiment that the people of Winnipeg and the people of New Orleans have in common the feeling that the East and West of the continent have taken too much for themselves. The central part of this continent must and will be developed. A great artery will run from North to South, and through it will pulse the heartbeats of commerce of the two great countries, the United States and Canada. The birds and geese and ducks show the way that should be followed by the people along the Jefferson Highway. The people of New Orleans should come north to Winnipeg when the weather gets hot down South, and the people of Winnipeg should come south to New Orleans when it gets cold in Winnipeg.

The visit of the Pine to Palm party was repaid in the fall of 1926 by a Louisiana party headed by Mayor Arthur O'Keefe of New Orleans, the party driving through to Winnipeg over the Jefferson Highway and arriving on schedule time. 
On The Pine to Palm tour an inspiring meeting was held at Longview, Texas, on February 2, 1926, at which one of the banquet speakers brought out the point that if there had been a number of north and south highways before the Civil War with easy means of communication and acquaintance and understanding between the various sections of the country, that there would have been no war between the states, but the differences would have been settled by friendly agreement.

The Spanish American War brought the northern soldiers under the command of General "Fighting Joe Wheeler" and in the World War our boys from North and South fought side by side in France and grew to love and understand each other. Colonel William J. Tucker, editor of the Longviezo Daily Nezos, called attention to the fact that in the World War he was closely associated with Colonel Guy Brewer of Des Moines in the One Hundred and Sixty-eighth Infantry.

Let it be noted, on this beautiful May morning, long observed as Memorial Day, sacred to the memory of the brave soldiers who have passcd to the great beyond, that with acquaintance comes understanding, and understanding is followed by an appreciation which ripens into friendship and love.

The closer association of communities and individuals both neighboring and distant, causes sectional lines to be obliterated and doubts and mistrust to be banished. In this work of promoting peace and good will, the building of good roads and the establishment of trunk lines and international lighways has played an important part.

\section{STEAM FERRY}

We learn by the Captain of the St. Ange, that the steam ferryboat, destined to ply across the Missouri River at California City, below the Platte, is on its way from St. Louis to its destined point, where emigrants may be crossed by the wholesale. Californians, come down below the Mouth of the Platte and try us. We already have a good flat boat in operation.

Andrew J. Stewart. -Platte City, April 17, 1850.-The Frontier Guardian, Kanesville (Council Bluffs), Iowa, June 12, 1850. (In the Newspaper Division of the Historical, Memorial and Art Department of Iowa.) 
Copyright of Annals of Iowa is the property of State of Iowa, by \& through the State Historical Society of Iowa and its content may not be copied or emailed to multiple sites or posted to a listserv without the copyright holder's express written permission. However, users may print, download, or email articles for individual use. 